\title{
Die aanwending van 'n kwalitatiewe metodologiese model in gesinsmoordnavorsing: 'n Suid-Afrikaanse gevallestudie
}

\author{
W.J. Schurink \\ Hoof: Misdaad en Verwante Studies \\ Groep: Samelewingsdinamika \\ Raad vir Geesteswetenskaplike Navorsing \\ PRETORIA
}

\begin{abstract}
In the light of limiled research on family violence and the fact that the phenomenon of family murder has generally not been researched systematically in South Africa, this article provides an exposition of the way in which family murder has been studied qualitatively in a recent HSRC project. In accordance with current views on criteria for evaluating qualitative studies, a natural history of the most important decisions taken during the execution of the reseanch is presented. In addition, the article indicates how the study complies with the standards of qualitative research.
\end{abstract}

\section{INI EIDING}

Die sistematiese insameling van gegewens oor gesinsgeweld is geen maklike taak nie. Joseph Weis (1989:127) skryf in hierdie verband soos volg:

Research on family violence is research on a sensitive topic in a sensitive setting. The family is a difficult social institution to study, and made more difficult when the topic of inquiry is violent behavior between offenders and victims who typically have close, personal relationships.

Benewens hierdie algemene struikelblokke word die sosiaal-wetenskaplike wat gesinsmoord ondersoek met etlike spesifieke probleme gekonfronteer. So word in amptelik gedokumenteerde databronne nie tussen gesinsmoord en ander vorme van moord onderskei nie, is informante (vriende, bure, grootouers en oorlewende kinders en eggenote(s) en ander persone aan wie die oorledenes bekend was) in 'n geskokte toestand en of nie in staat of nie bereid om 'n navorser te woord te staan nie en is belangrike inligtingsbronne soos die moordenaar en/of sy/haar slagoffers nie beskikbaar nie.

Dit is dan ook nie vreemd nie dat navorsing oor gesinsgeweld in vergelyking met ander navorsing relatief beperk is. Wat die stand van Suid-Afrikaanse navorsing oor gesinsgeweld betref, skryf Pretorius (1987:439): 
On the whole it seems that only a limited amount of research on family violence has been done in South Africa and whatever research has in fact been conducted, appears to deal mainly with the abuse of women and children.

Wat gesinsmoordnavorsing hier te lande betref, lê die veld nog grootliks braak (vgl. Pretorius 1987:439) hoewel Suid-Afrikaanse ondersoekers dié vorm van gesinsgeweld die afgelope tyd toenemend begin bestudeer het (vgl. Viljoen, 1988; Olivier, 1988; De Jongh van Arkel, 1988; Snyman, 1989; Roos \& Bodemer, 1989; Du Toit, 1990; Pretorius, 1990; Graser, 1991 \& 1992).

In die lig van die min wetenskaplike kennis oor gesinsmoord, die feit dat dit komplekser is as wat aanvanklik gereken is en die behoefte aan omvattende navorsing oor die verskynsel, het die Raad vir Geesteswetenskaplike Navorsing (RGN) op versoek van die Departement van Nasionale Gesondheid en Bevolkingsontwikkeling besluit om 'n betreklik omvattende studie daaroor te loods. Die ondersoek kan in terme van die navorsingstrategieë wat gevolg is in twee dele verdeel word: die opname- en gevallestudiedele.

Ten einde 'n diepgaande studie van 'n aantal outentieke gevalle van gesinsmoord te maak, is besluit om van 'n kwalitatiewe navorsingsmodel gebruik te maak. Meer spesifiek is veral ' $n$ ideografiese (Windelband aangehaal deur Mouton \& Marais, 1985:30), holistiese (Patton, 1980) of kontekstuele (Mouton \& Marais, 1985) model gevolg en is 'sagte' metodes, te wete ongestruktureerde onderhoude, persoonlike en ander dokumentêre materiaal en deelnemende waarneming geïmplementeer (Olivier et al., 1991). Hierdie metodes het 'n ryke verskeidenheid gegewens oor gesinsmoord gegenereer wat gelei het tot waardevolle insigte in fasette soos byvoorbeeld: die persoonlikhede en gedragstyle van die moordenaar en die huweliksmaat, die proses wat tot gesinsmoord lei, die motief vir asook die metode van gesinsmoord en die gedrag van gesinslede en hul betrokkenheid by hul uitgebreide gesinne (Olivier et al. 1991). Suid-Afrikaners het tot nog toe in sowel sosiaal-wetenskaplike navorsing in die algemeen as in afwykende gedragsnavorsing, kriminologiese en viktimologiese navorsing in die besonder, grootliks van kwantitatiewe metodes gebruik gemaak.

Hoewel dié metodes steeds die plaaslike navorsingstoneel oorheers, het verskeie studies in die jongste tyd die lig gesien wat as kwalitatief beskou kan word (vgl. ondermeer Schurink, 1979, 1981 \& 1989; Schurink \& Winterbach, 1979; Schurink \& Ndabandaba, 1991; Lőtter \& Schurink, 1986; Pretorius, 1982; Schulze, 1988; Minnaar, Offringa \& Payze, 1992; Engelbrecht, 1991; die bundel van Hugo, 1990).

Ten spyte van die toename in gewildheid en vindingrykheid van kwalitatiewe studies die afgelope tyd, tas kwalitatiewe navorsers nog dikwels in die donker wanneer dit kom 
by die praktiese toepassing van die kwalitatiewe navorsingstyl. Metodologiehandboeke en monografieë en bundels wat aspekte van hierdie benadering behandel, verskaf weliswaar belangrike riglyne oor hoe sodanige navorsing uitgevoer moet word. Dergelike riglyne kan egter nie as vaste 'resepte' beskou word nie en kan hoogstens die bestanddele daarvan suggereer. Die gebrek aan sodanige resepte is nie vreemd nie omdat

- die kwalitatiewe navorsingsproses voortdurend beïnvloed word deur die navorser(s), die subjek(te) en die ondersoekmetode(s) wat gebruik word, die probleme wat ondervind én oorbrug moet word en die tipes data wat ingesamel word, en

- die feit dat kwalitatiewe navorsing 'n buigbare proses is waartydens verskillende besluitnemingstappe voortdurend (en soms terselfdertyd) en nie volgens 'n tydsvolgorde geneem word nie.

Teen die agtergrond van die voorgaande word die klem in hierdie artikel op die sosiale proses van kwalitatiewe navorsing geplaas en word die praktiese verloop en geloofwaardigheid van die gevallestudiedeel van die RGN-gesinsmoordprojek beskryf. Die oogmerk is egter nie om hierdie verwikkelde proses in detail weer te gee nie. So 'n opgaaf val uiteraard weens die ruimtebeperking buite bestek van die artikel.' Die doel met hierdie artikel is om die leser 'n idee te gee van die praktiese verloop van kwalitatiewe navorsing en om hom of haar terselfdertyd te help om dit te evalueer. Alvorens dit gedoen word, word kwalitatiewe navorsing asook belangrike oorwegings vir die evaluering van kwalitatiewe navorsing kortliks beskryf.

\section{KWALITATIEWE NAVORSING}

\section{$2.1 \quad$ Terminologiese omskrywings}

Kwalitatiewe navorsing is soos Babbie (1989:261) tereg aantoon 'n navorsingstyl wat in die geesteswetenskaplike praktyk baie oud en baie nuut is. Kwalitatiewe navorsing is baie oud omdat die ontstaan van die benadering teruggevoer kan word na die einde van die vorige eeu. Dit is egter ook baie nuut omdat dit sedert die sestigerjare van die huidige eeu, toenemend die aandag van verskeie sosiaalwetenskaplikes (bv. sosiale antropoloë, sosioloë, ekonome, politieke wetenskaplikes, opvoedkundiges, psigoloë, kriminoloë, maatskaplike werkers en verpleegkundiges) geniet. Kundiges wat van

1 in Volledige uileenselling van die aanwending van die kwalitatiewe metodologic in dic ondersock word egter in Olivier et al. (1991) verskaf, en dic geinteresseerde leser word versoek om dié bron te raadpleeg. 
Die aanwending van 'n kwalitatiewe metodologiese model in gesinsmoordnavorsing

kwalitatiewe navorsing gebruik maak, werk op terreine soos afwykende gedrag, viktimologie, sport (bv. die leefwêreld van swembadbestuurders), gesondheid (bv. hospitale en klinieke) en kleding (bv. die betekenis van kledingpraktyke). Die kwalitatiewe metodologie het onlangs selfs die terrein van maatskaplike-dienste-evaluering, 'n vorm van toegepaste navorsing, binnegedring (vgl. Goodwin \& Goodwin, 1984; Patton, 1990; Bogdan \& Taylor, 1990).

Die tempo waarteen artikels en boeke wat oor kwalitatiewe navorsing handel die lig gesien het, het in die jongste tyd dramaties toegeneem. Vandag is daar nie net talle bundels en monografieë wat oor dié navorsingstyl handel beskikbaar nie 2 maar word ook vakwetenskaplike tydskrifte aangetref wat aan sodanige navorsing gewy word. 3

'n Verskeidenheid terme word met die konsep kwalitatief in verband gebring en dit is dan ook nie vreemd nie dat daar tans nie 'n algemeen aanvaarbare omskrywing daarvan onder sosiaal-wetenskaplikes is nie (vgl. Van Maanen, 1979:520; Lofland \& Lofland, 1984:3). Verskeie sinonieme vir kwalitatiewe navorsing soos veldnavorsing, naturalisme, etnografie, interpretatiewe navorsing, en gevallestudie word in die literatuur aangetref. Veldnavorsing of veldwerk dui daarop dat hierdie tipe navorsing normaalweg onderneem word in die habitat van die persone wat bestudeer word. Dié term is nou verwant aan naturalistiese navorsing en impliseer

- dat vooropgesette idees waarmee die navorser die empiriese wêreld of besondere verskynsel wat hy/sy bestudeer mag benader, sover moontlik beperk moet word en

- dat die navorser nie die verskynsel wat ondersoek word, sal manipuleer nie. Volgens Lofland \& Lofland (1984:3) impliseer dit "... a close and searching description of the mundane details of everyday life ... "

Hoewel daar heelwat verwarring rondom etnografie aangetref word, dui dit veral op die oorheersend beskrywende aard van kwalitatiewe navorsing (Mouton, 1988:1). Die term

$2 \quad$ Vergelyk Bogdan \& Taylor (1975); Schwartz \& Jacobs (1979); Smith \& Manning (1982) Burgess (1982, 1984, 1985); Bogdan \& Biklen (1982); Emerson (1983); Van Maanen (1983); Lofland \& Lofland (1984); Taylor \& Bogdan (1984); Parse, Coyne \& Smith (1985) Ficld \& Morse (1985) Walker (1985); Leininger (1985); Punch (1986); Kirk \& Miller (1986) Chenitz $\&$ Swanson (1986); Wester (1987); Straus (1987); Gubrium (1988); Pfaffenberger (1988); Marshall \& Rossman (1989); Jorgensen (1989); Strauss \& Corbin (1990); Patton (1990); Shaffir \& Stcbbins (1991)

3 Vergelyk Journal of Contemporary Ethnography (voorheen Urban Life) en Qualitative Sociology. 
interpretatief verwys volgens Mouton (1988:1) na die feit dat dit in sodanige navorsing nie gaan om menslike gedrag te verklaar in terme van algemeen-geldende wette nie, maar eerder om die betekenisse en simbole te verstaan wat onderliggend aan menslike handelinge is. Gevallestudie verwys na die ideografiese strategie wat tipies in kwalitatiewe navorsing gevolg word. Dit beteken dus dat die oogmerk met dergelike navorsing nie is om te veralgemeen nie maar eerder om ' $n$ enkele geval of ' $n$ klein aantal gevalle indringend te ondersoek. Ten slotte bied $k$ walitatief, sekerlik die term wat die omvattendste is en die meesțe aangewend word, 'n aanduiding dat dié navorsing die kwaliteite van menslike optrede benadruk, dit wil sê op die kwalitatiewe en nie op die kwantitatief-meetbare elemente van menslike gedrag konsentreer nie.

\subsection{Aspekte eie aan kwalitatiewe navorsing}

Uit die voorgaande behoort dit duidelik te wees dat kwalitatiewe navorsing en sy sinonieme minstens een aspek gemeen het, te wete die verheldering van die sin en betekenis wat mense aan sosiale situasies heg. Ander basiese kenmerke van kwalitatiewe studies, is die volgende:

* Kwalitatiewe navorsing is induktief. Eksponente van hierdie benadering ontwikkel konsepte, insig en begrip van gegewens eerder as wat hulle op soek is na data aan die hand waarvan vooropgesette teoretiese begrippe (hipoteses, teorieë of modelle) getoets kan word. 'n Plooibare navorsingsontwerp word tipies gevolg en aanvanklik word slegs van vaag omskryfde vrae gebruik gemaak. Binne hierdie raamwerk word teorieë en ander konstrukte ontwikkel "... from the bottom up (rather than from the top down), from many disparate pieces of collected evidence that are interconnected. It is called grounded theory ..." (Bogdan \& Biklen, 1982:29).

- Kwalitatiewe navorsing is holisties. Kwalitatiewe navorsers reduseer situasies, groepe of mense nie na veranderlikes nie, maar beskou dit binne die konteks waarbinne dit aangetref word.

The setting has to be understood in the conlext of the history of the institutions of which they are a part. When the data with which they are concerned is produced by subjects, as in the case of official records, they want to know where, how and under what circumstances it came into being. Of what historical circumstances and movements are they a part? To divorce the act, word, or gesture from its context is, for the qualitative researcher, to lose sight of signilicance (Bogdan \& Biklen, 1982:27). 
* Kwalitatiewe navorsers is begaan oor die uitwerking wat hulle op die respondente of subjekte het.

Qualitative research has been described as naturalistic. That is, researchers interact with informants in a natural and unobtrusive manner. In participant observation they try to 'blend into the woodwork', at least until they have grasped an understanding of a setting. In in-depth interviewing they model their interviews after a normal conversation, rather than a formal question and answer exchange (Taylor \& Bogdan, 1984:6).

Hoewel kwalitatiewe navorsers natuurlik nie die effek wat hulle op die subjekte het, kan uitskakel nie, poog hulle om dergelike steuringveranderlikes te beperk of probeer hulle ten minste om daarmee rekening te hou wanneer hulle die gegewens interpreteer.

* Kwalitatiewe navorsers trag om mense in terme van laasgenoemde se eie verwysingsraamwerk te begryp. Kwalitatiewe navorsers is daarop ingestel om die verskillende wyses waarvolgens mense sin aan hul lewens gee vas te stel. Hulle identifiseer en empatiseer met subjekte in 'n poging om die betekenisse (meanings) wat laasgenoemde aan hul lewens heg te begryp.

In other words, qualitative researchers are concerned with what are called participant perspectives. They focus on questions like: What assumptions do people make about their lives? What do they take for granted (Bogdan \& Biklen, 1982:29-30).

- Kwalitatiewe navorsers skort hul eie opvattings, perspektiewe en vooroordele op. Hulle beskou menslike gedrag, situasies en sosiale prosesse asof dit vir die eerste keer plaasvind. Niks word as vanselfsprekend beskou nie en alles word aan navorsing onderwerp.

* Alle perspektiewe is vir kwalitatiewe navorsers van belang. Hulle is nie op soek na die 'waarheid' of 'moraliteit' nie, maar streef eerder daarna om ander persone se perspektiewe te verstaan. Verder beskou hulle alle mense as gelykes.

Thus the juvenile delinquents' perspective is just as important as the judge's or counsclor's; the 'paranoid's' just as important as the psychiatrist's (Taylor \& Bogdan, 1984:6).

- Kwalitatiewe metodes is humanisties. Anders as kwantitatiewe metodes wat mense se handelinge en woorde staties voorstel, fokus kwalitatiewe metodes op die menslike aspek van sosiale gedrag. Kwalitatiewe navorsers leer die subjekte persoonlik ken en ondervind wat laasgenoemde in hul alledaagse handel en wandel beleef. 
* Kwalitatiewe navorsers beklemtoon die prosesuele (processional) dubbelsinnige en dinamiese aard van menslike gedrag. Anders as kwantitatiewe navorsers wat in hul soeke na veralgemenings probeer om menslike gedrag te orden en te rasionaliseer en sodoende die dubbelsinnighede en problematiese en chaotiese werklikhede van die sosiale lewe miskyk, trag kwalitatiewe navorsers om die onbestendigheid, besluiteloosheid, teenstrydighede en verwarring wat menslike gedrag kenmerk, bloot te lê.

- Kwalitatiewe navorsers benadruk die geldigheid van navorsingbevindinge. Kwalitatiewe metodes stel die navorser in staat om naby aan die wêreld van subjekte te kom deur te luister waaroor subjekte praat en te kyk na dokumente wat deur laasgenoemde opgestel is. Sodoende verkry die kwalitatiewe navorser eerstehandse kennis van die sosiale lewe wat nie deur abstrakte konstrukte, geoperasionaliseerde definisies en beoordelingskale gekontamineer word nie.

- Kwalitatiewe navorsing is beskrywend. Gegewens word eerder in die vorm van woorde en foto's as syfers versamel. Die geskrewe resultate van die navorsing bestaan uit uittreksels uit onderhoudtranskripsies, veldnotas, persoonlike dokumente, amptelike gegewens en video-opnames en foto's.

In their search for understanding, qualitative researchers do not reduce the pages upon pages of narration and other data to numerical symbols. They try to analyzc it with all its richness as closely as possible to the form in which it was recorded or transcribed (Bogdan \& Biklen, 1982:28)

- In kwalitatiewe navorsing kan alle situasies en mense bestudeer word. Vir kwalitatiewe navorsers is geen aspek van die sosiale lewe te wêrelds, beuselagtig of onbelangrik nie. Alle situasies en mense is vir hulle tegelykertyd eenders en uniek.

They are similar in the sense that some general social processes may be found in any selting or among any group of people. They are unique in that some aspect of social life can best be studicd in each setting or through each informant because there it is best illuminated ... (Taylor \& Bogdan, 1984:8).

- Kwalitatiewe navorsing is ' $n$ kuns. Kwalitatiewe metodes is nie tot dieselfde mate as kwantitatiewe metodes verfyn en gestandaardiseerd nie en 'n oop en plooibare benadering word in sodanige navorsing gevolg.

The researcher is a craftsperson. The qualitative social scientist is encouraged to be his or her own methodologist ... There are guidelines to be followed, but never rules. The methods serve the researcher; never is the researcher a slave to procedure and technique ... (Taylor \& Bogdan, 1984:8). 


\section{ENKEI F BREë RIGLYNE VIR DIE BEOORDELING VAN KWALITATIEWE STUDIES}

Anders as in die geval van kwantitatiewe navorsing is daar 'n gebrek aan duidelik geformuleerde kriteria vir die evaluering van kwalitatiewe navorsing (vgl. Athens, 1984). Hoewel sommige eksponente van kwalitatiewe navorsing argumenteer dat eksplisiete kriteria vir die beoordeling van dergelike navorsing onvanpas is, het ander soos Athens (1984) en Marshall en Rossman (1989:144) gelyk as hulle daarop wys dat riglyne aan die hand waarvan dié navorsing geëvalueer word, dringend benodig word. Athens (1984:267) stel dit so:

\footnotetext{
... the time has passed when qualitative studies can be judged on the basis of sociological intuition, unknown criteria, or even worse, modified positivistic critcria ... Qualitative sociologists must begin to make much more explicit their basis for determining the scientific value of different qualitative studies than they have thus far.
}

Dit beteken egter nie, soos reeds gesuggereer, dat kwalitatiewe navorsers hul studies in terme van kwantitatiewe navorsingstandaarde moet begin meet nie! Bestaande wetenskaplike standaarde moet eerder soos Strauss en Corbin (1990:250) voorstel, geherdefinieer word sodat dit sal pas by die realiteite van kwalitatiewe navorsing en by die ingewikkeldheid van die maatskaplike verskynsels wat begryp moet word.

Lesers van kwalitatiewe navorsingsverslae evalueer die studies uit die aard van die saak op een of ander wyse. Athens (1984:261) skryf soos volg oor hierdie ongespesifiseerde evalueringsmaatstawwe:

(T)he real question is ... whether or not these criteria should be formulated and thereby made explicit or remain unformulated and implicit. I believe that it is far more advantageous to have cxplicilly stated criteria for judging studies than to have unstated ones. As long as the criteria remain unstated and implicit, qualitative sociologists can never be quite sure what critcria will be used in judging their work and consequently what criteria, if any, they should kecp in mind while conducting their studies. When qualitative sociologists judge studies to one degrec or another on the basis of their own unstated pet criteria, a certain amount of general intellectual confusion is bound to result.

In die lig van Athens se aanbeveling het die skrywer tydens die verloop van die gesinsmoordgevallestudie breë riglyne vir die beoordeling daarvan opgestel. Die navorsers is versoek om hierdie riglyne in die skryf van hul veldnotas in gedagte te hou. Vervolgens word die ondersoek aan die hand van dié riglyne bespreek. 


\section{NATUURLIKE VERLOOP VAN DIE ONDERSOEK}

In die hieropvolgende verslagdoening van die gesinsmoordgevallestudie word eerstens 'n chronologiese uiteensetting gegee van die belangrikste besluite wat tydens die praktiese uitvoering daarvan geneem is, en tweedens word aangedui hoe daar gepoog is om steuringsfaktore te bekamp ten einde die kwaliteit van die resultate te verhoog. Aangesien hierdie ondersoek nie losgemaak kan word van filosofiese vooronderstellings en breë teoretiese raamwerke thie, sal vooraf baie kortliks hierby stilgestaan word.

\subsection{Wetenskapsopvattings}

'n Diversiteit van perspektiewe ten opsigte van die samelewing, die mens, dimensies van gesinsmoord, watter aspekte van gesinsmoord ondersoek behoort te word, wat goeie wetenskap behels, en hoe geldige navorsingsresultate verkry moet word, is onder die navorsers aangetref. Die wetenskaplikes wat die maatskaplike werk, kriminologie, sielkunde, sosiologie, teologie en psigiatrie verteenwoordig het, se metateoretiese aannames kan breedweg teruggevoer word na die twee algemene wetenskapsbeelde in die geesteswetenskappe, naamlik die positivisme en die antipositivisme of humanisme.

Die verskillende aannames onder die navorsers het nooit tot enige ernstige of langdurige geskille of uitbarstings aanleiding gegee nie. Hoewel dié betreklik gladde verloop van die ondersoek aan verskeie faktore toegeskryf kan word, was die vernaamste een ongetwyfeld die vasberadenheid onder die navorsers om die mees geldige bevindinge oor die verskynsel van gesinsmoord te bekom. Aan die positiewe kant het die feit dat navorsers uit verskillende dissiplines, met 'n verskeidenheid van filosofiese en teoretiese aannames die ondersoek uitgevoer het, meegebring dat gesinsmoord vanuit ver-

- skeie hoeke belig kon word - 'n benaderingswyse wat tot'n beter greep daarop gelei het.

\subsection{Teoretiese konstrukte}

Verskeie algemene teoretiese raamwerke (formele teorieë) en gesinsgeweld- en gesinsmoordteorieë (substantiewe teorieë) is tydens die uitvoering van die navorsing gevolg (vgl. Olivier et al., 1991). Hoewel dit as ideaal gestel was dat die subjekte se belewenisse van gesinsmoord eers ontrafel moes word, waarna dit met abstrakte simboliese gereedskap (konsepte, tipologieë, teorieë en modelle) verder beskryf en verklaar moes word, het dit nie altyd gerealiseer nie. Sommige van die navorsers kon 
nie daarin slaag om hulself aanvanklik van bestaande konstrukte los te maak nie. Hoewel dié konstrukte uiteraard die inligting wat van die subjekte verkry is, beïnvloed het, is genoegsame ruimte aan hulle gelaat om namens hulself te praat. Elemente van albei wetenskapsbeelde blyk onder meer uit die feit dat dit in die onderhawige ondersoek nie net om die begryp of verstaan van gesinsmoord gegaan het nie, maar ook oor die eksaminering van etiologiese teorieë en ander bestaande konstrukte. Skeptici mag beweer dat weens die aandag aan kousaliteit die studie gedeeltelik tot 'n ontologie gekompromitteer was waarvolgens menslike handelinge deur eksterne en/of interne magte/wette gedetermineer word en die mens baie min, indien enige, vrye keuse in sy wilsuitoefening veroorloof word. Dit is egter nie korrek dat daar in die studie min of geen ruimte gelaat is vir vrye menslike handeling nie. In aansluiting by Mouton en Marais (1985:47-48) is van die standpunt uitgegaan dat kousaliteit deel van menslike gedrag vorm sonder dat daar enige onderliggende wetmatigheid hoef te wees. Redes wat deur oorlewende gesinslede en ander subjekte vir die moordenaar en/of die slagoffers se optredes verstrek is, is dan ook as oorsake van laasgenoemdes se gedrag beskou.

\subsection{Besluite en stappe wat tydens die ondersoek geneem is}

Teen die agtergrond van die filosofiese en teoretiese aannames wat 'n rol in die onderhawige ondersoek gespeel het, sal die besluite en stappe wat in die uitvoering daarvan geneem is nou van nader bekyk word. Dit is egter belangrik om vooraf op die volgende belangrike sake te let:

- Dit is nóg prakties moontlik nóg wenslik om 'n volledige uiteensetting van alle relevante besluite te gee, ${ }^{4}$ en

* hoewel die belangrikste besluite en stappe in hierdie gedeelte bespreek sal word ooreenkomstig die tydstip waarop dit tipies geskied het, dit weens die hoogs

4 Uit die toepaslike literatuur blyk dit dat daar hoofsaaklik drie strategiee bestaan wat gevolg kan word om die geloofwaardigheid van 'n kwalitatiewe strategie te bcpaal (vgl. Platt, 1981:53-66). Dergelike strategieë wissel tussen 'n baie volledige beskrywing van die stappe en besluite wat tydens die studie geneem is asook die aanbicding van alle of bykans alle verkreē data. 'n Uitvocrige uiteensetting van alle besluite en stappe wat geneem is en 'n volledige weergawe van alle data kan ontaard om soos Ackroyd en Hughes (1981:113) tercg opmerk: "... quite probably bore a reader or bury him (or her) in a surfeit of information" tc wees. Daarom is in navolging van Becker (1970:37) besluit om nie clke datum van die gesinsmoordgevallestudie aan te bied nie maar slegs die kenmerkende vorme wat data tydens elke stadium van die navorsing aangeneem het. 
veranderlike karakter van die navorsingsproses in werklikheid geensins georden en chronologies verloop het nie.

Dit is tiperend van kwalitatiewe navorsing om in fases plaas te vind. Uit relevante literatuur blyk dat veral drie fases of stadia in die kwalitatiewe navorsingsproses onderskei kan word. Die fases is: die aanvangs- of toegangsfase, die middel- of basiese data-insamelingsfase en die finale of eindfase (Schurink, 1989:83). Wanneer in retrospek na die huidige ondersoek gekyk word, blyk dat ook die studie in die genoemde fases ingedeel kan word. Die fases word vervolgens nader toegelig.

\subsubsection{Die aanvangsfase}

Die aanvangsfase het vanaf Junie 1988 tot einde Maart 1989 gestrek. Die belangrikste aspekte tydens die eerste stadium van die ondersoek was:

- Die eerste onderhandelinge tussen dr. Louise Olivier, die projekleier, en mev. Martha Landman en mej. Pretorius van die Departement van Nasionale Gesondheid en Bevolkingsontwikkeling insake navorsing oor die verskynsel van gesinsmoord in Suid-Afrika.

- Die voorbereiding van 'n navorsingsvoorstel vir voorlegging aan die Departement.

- Die formele aanvaarding van diê voorstel deur die Departement in sy brief van 4 Augustus 1988. Benewens die gevallestudieprojek waaroor hier verslag gedoen word, is die sosiale opname geloods onder professionele persone gemoeid met die verskynsel van gesinsmoord, terwyl die ontwikkeling van intervensie- en behandelingstrategieë ook goedgekeur is.

- 'n Uitgebreide soektog na literatuur oor gesinsmoord en verwante verskynsels in sowel sosiaal-wetenskaplike as populêre bronne.

- Die identifisering van kundige persone vir die samestelling van 'n 'vestigingskomitee'. Nadat verskeie persone geïdentifiseer en telefonies deur die projekleier om lidmaatskap van die komitee gepols is, is belangstellendes skriftelik na die eerste vestigingskomiteevergadering genooi wat vir 25 November 1988 by die RGN geskeduleer was. 
- Tydens dié vergadering wat deur verteenwoordigers van die opdraggewer, die RGN, die Suid-Afrikaanse Polisie en akademici en professionele persone verbonde aan verskeie universiteite en hulpverlenende instansies bygewoon is, is verskeie belangrike besluite geneem. Eerstens is ' $n$ werksdefinisie van gesinsmoord geformuleer. Die definisie is vasgestel nadat die komiteelede wat in klein groepe verdeel was voorlopige definisies voorgestel het (vgl. Olivier et al., 1991). Tweedens is besluit om met die oog op die indringende studie van gesinsmoordgevalle statistiek vir 'n gegewe tydperk van die Suid-Afrikaanse Polisie te probeer verkry. Hierbenewens sou inligting oor die volgende van die Mag versoek word: 1.1 Wie het die moord gepleeg? 1.2 Was daar 'n selfmoordpoging direk daama? 1.3 Was daar mense buite die gesin betrokke en onder watter omstandighede? (Notule van die Vestigingskomiteevergadering 1988-11-25).

* Die samestelling van spanne wat die gevalle van gesinsmoord ondersoek het. Daar 'n studie van gesinsmoord emosioneel en andersins hoë eise aan navorsers stel, is tydens die eerste vergadering van die gevallestudiekomitee op 17 Maart 1989 besluit om die lede in spanne in te deel wat vir die duur van die navorsing die gevalle van gesinsmoord sou ondersoek. Die belangrikste oorwegings tydens die samestelling van die navorsingspanne was: die spanlede moes nie almal van dieselfde geslag wees nie; minstens een persoon moes van die RGN wees; en ten minste een van die spanlede moes 'n sielkundige wees. Dié ideale het egter nie altyd in die praktyk gerealiseer nie en normaalweg het die eerste drie komiteelede wat beskikbaar was 'n span gevorm.

- 'n Studie van amptelike lêers. 'n Aantal offisiële lêers met inligting aangaande gesinsmoorde wat reeds op daardie stadium in Suid-Afrika voorgekom het is deurgewerk. Die gedagte was om insigte wat uit die databron verkry kon word, met die oog op onderhoudvoering, as agtergrond te gebruik.

- Riglyne vir die analise en interpretasie van kwalitatiewe data. Daar is tydens die vergadering van 17 Maart 1989 besluit dat die skrywer 'n memorandum vir die navorsers sou opstel waarin die toepassing van die kwalitatiewe benadering toegelig word.

- Identiteitskaartjies vir die navorsers. Dergelike kaartjies wat deur sowel die President van die RGN as die Kommissaris van die Suid-Afrikaanse Polisie onderteken is, het benewens ' $n$ foto en die identiteitsnommer van die navorser, die volgende in Afrikaans en Engels bevat: "Hiermee word gesertifiseer dat (naam van navorser) lid is van die navorsingspan (gesinsmoord)". 
* Voorlopige begrensing van die ondersoek. Tydens genoemde vergadering is ooreengekom dat die eerste twaalf gevalle van gesinsmoord (drie elk onder blankes, swartes, kleurlinge en Asiërs) wat vanaf 1 April 1989 by die Suid-Afrikaanse Polisie aangemeld word, by die studie betrek sou word.

\subsubsection{Data-insamelingsfase}

Die gegewens is oor 'n periode van 18 maande ingesamel en wel vanaf 1 April 1989 tot Oktober 1990. Inligting is ten opsigte van twaalf gevalle versamel. Een van die gevalle waar almal aan die dood ontsnap het, word egter nie as 'n gesinsmoord beskou nie. Die wyses waarvolgens die data in die onderhawige ondersoek ingesamel is, het in sekere opsigte dramaties verskil en in ander gevalle groot ooreenkomste getoon. Dit blyk duidelik wanneer die metodologiese verslae van die onderskeie navorsingspanne in oënskou geneem word. Dié verslae wat in eie reg ryk databronne is, kan as natuurlike geskiedenisse van die elf gevallestudies beskou word. Daar hierdie natuurlike geskiedenisse in die kleine goeie toeligting verskaf van veral die stappe en besluite wat tydens die versameling van die data geneem is, word in die hiervolgende bespreking swaar op dié verslae geleun. Daar sal dan ook vrylik daaruit aangehaal word. Teen dié agtergrond word die belangrikste elemente in die data-insamelingsfase van die huidige studie vervolgens nader beskryf.

4.32.1 Opsporing van gevalle. Die opsporing van gevalle van gesinsmoord was in die algemeen gesproke nie problematies nie. Toestemming is van die Suid-Afrikaanse Polisie verkry dat voorvalle van gesinsmoord wat in die Mag se daaglikse misdaadopgawe opgeneem word so gou moontlik aan die projekleier deurgestuur word. Kern- agtige inligting aangaande alle ernstige misdade wat onder die Suid-Afrikaanse Polisie se aandag kom, word daagliks na die Polisiehoofkwartier in Pretoria gefaks. Nege gevalle $(1,2,3,5,6,7,8,9$ en 10) is met behulp van die opname opgespoor. Die geval waar 'n vader gedreig het om sy gesin te vermoor (geval 4) is deur die sielkundige by wie die moeder om hulp aangeklop het, onder die navorsers se aandag gebring. Die navorsers het te hore gekom van die swart vrou wat haar drie kinders vermoor het maar nie daarin kon slaag om haarself om die lewe te bring nie (geval 11) toe sy na 'n plaaslike psigiatriese hospitaal verwys is.

4.3.2.2 Polisiestasiepersoneel as fasiliteerders van databronne. Beamptes verbonde aan die polisiestasie wat diens doen in die area waar die gesinsmoorde gepleeg is, was 
die belangrikste fasiliteerders van sowel inligting aangaande die moorde as persone wat die oorledenes geken het en wat om inligting genader kon word. Ander instansies of persone wat as fasiliteerders opgetree het, was onder meer werkgewers van die oorledenes, skoolhoofde, Weskoppies-Hospitaal en die Departement van Justisie. Hoewel die polisiestasiepersoneel in alle gevalle met die navorsers saamgewerk het, was daar gevalle waar sommige van die beamptes die navorsers met agterdog bejeën het en/of sekere inligting teruggehou het. Die volgende dien as voorbeelde:

- The officer in charge received the research team in a friendly manner and was very helpful throughout the interview. However, as can be expected, he was very uneasy at first about recording the interview. The researchers assured him that all the information that he would give to them, would be treated in the strictest confidence. He offered to show the team a video of the scene of the murder, but remained uneasy about recording the interview. The researcher (sensing the nervousness of the officer turned the tape off). As the relationship of trust between the researchers and the respondent developed the officer was more at ease. The sergeant who had also investigated the case, joined the party in a very informal manner. After reassuring him that all the information received by them would be treated in a confidential manner, he was at case and even ventured to share some of his theories with the research team. The researchers gained the most information and insight into their side of the story when the officers spontaneously started talking among each other about the case and started speculating why they thought it could have happened. The researchers were impressed by the honest and sincere manner in which the officers dealt with the case as well as their concern about the two family murders that had taken place in their area within a sixth-month period (methodological note by tcam 5).

- Die bevelvoerder het die navorsingspan in kontak geplaas met die ondersoekbeampte en die ondersoekbeample het dan ook die ondersoekspan inligting gegec aangaande die insident. Hy het dit egter eers gedoen nadat hy die ondersockspan 'siclkundig' getocts het deur die ondersockspan tc konfronteer met foto's van ' $n$ persoon wat homself om die lewe gebring het deur groot stukke vleis uit homself te sny en uiteindelik sy cie nek af te sny. Hierdie foto's was uiters grusaam en skokkend (metodologieverslag deur span 3).

Uit die ervarings wat die navorsingspanne gehad het, blyk dat die navorsers se gesinsmoordnavorsing-identiteitskaartjies wat onderteken is deur die kommissaris van die Suid-Afrikaanse Polisie toegang tot polisiestasiebeamptes gewaarborg het, maar nie hul samewerking nie. Bogdan (1972:16-17) skryf soos volg oor navorsing in organisasies:

Different people in the organization have different degrees of receptivity to the observer, and although the gatekeeper (the person in charge) may open the organization to him, he may be doing so against the will or without the knowledge of others, particularly those lower in the organizational hierarchy. Getting in involves more than getting permission from gatekeepers; it also involves contacting others and seeking their cooperation. 
4.3.2.3 Seleksie van subjekte. Die navorsers het onderhoude gevoer met soveel moontlik persone wat kontak met die gesinne gehad het of oor kennis van die gesinslede beskik het ten einde so volledig moontlik die gesin en sy rolspelers te kon rekonstrueer. Uiteindelik is meer as vier dosyn onderhoude en/of informele gesprekke gevoer met polisiebeamptes, distriksgeneeshere, hofbeamptes, werkgewers, kollegas, predikante, skoolhoofde, joernaliste, huishulpe, bure, vriende, familielede, psigiaters, 'n eskortgesellin, lewensredders en twee persone wat hul gesinne wou uitwis/uitgewis het maar nie daarin kon slaag om hulself om die lewe te bring nie. Sekere belangrike persone kon egter nie by die studie betrek word nie. Die vernaamste redes hiervoor was dat van hierdie persone nie aan die navorsing wou deelneem nie, dit weens 'n druk program van die navorsingspan nie moontlik was om onderhoude met potensiele subjekte te voer wat geografies ver verwyder was van die plek waar die navorsingspanne gestasioneer was nie, en die navorsers sekere persone soos oorlewende familielede uit vrees dat ondervraging hulle sou ontstel of andersins sou benadeel, nie by die studie ingesluit het nie. Die volgende uittreksels uit die metodologieverslae van die navorsingspanne is relevant:

- Die navorsingspan kon nie 'n onderhoud voer met die ouers van die vrou van die moordenaar nie want hulle was geografies ver verwyderd van die Ioneel ... Die ondersoekspan kon nie die huishulp van die gesin opspoor nie ... ten spyte van die feil dat die ondersoekspan 'n ander huishulp genader het om haar te probeer opspoor (span 1).

- Die kwessie van onderhoude met die twee oorlewende dogters is 'n baie moeilike een. Die dogters is saam met die vermoorde vrou se moeder waarskynlik die persone wat die beste beeld van die leefwêreld van die gesin kan gee en juis om die rede behoorl ons hulle by onderhoudvoering te betrek. Wanneer na die eliese gekyk word en spesifiek dat die navorser veronderstel is om die subjekte teen enige vorm van benadeling te beskerm, lyk die risiko's dat die kinders en die ouma deur onderhoudvoering nadelig getref gaan word te groot en moet die belange van die wetenskap, selfs al is die doel van die huidige studie lofwaardig in sy strewe na oplossings vir gesinsmoorde, buig voor die van die kwesbare persone ... (span 6).

4.32.4 Volgorde van onderhoude. Hoewel die verloop van die onderhoudvoering by die onderskeie spanne verskil het (vgl. Olivier et al. (1991) vir 'n uiteensetting van dié data-insamelingsmetode), is sover moontlik getrag om by 'n besondere model te hou. Die model word nader toegelig deur die volgende uittreksels uit die metodologieverslae:

- Daar is besluit om wal die onderhoude betref, cers met die polisie en ander persone wat in 'n amptelike hoedanigheid met die gesin kontak gehad het te gesels. Verdere onderhoude met dic bure, werkgewers en kollcgas van sowel die man as die vrou, die huishulp, die skoolhoof en die sielkundige het hierna gevolg. Die onderhoude met die man (moordenaar) se broer, suster en swacr, en voog het 
eers later plaasgevind. Daar was vier redes vir hierdie prosedure. Eerstens was die polisieondersoek om verskeie redes vertraag en is ooreengekom dat die ondersoekbeampte eers sy ondervraging met die familielede sou afhandel voordat ons by hulle aanklop. Tweedens het ons gevoel dat die familielede eers deur die ondersoekbeampte oor die navorsing ingelig moes word. Derdens kon ons nie toe ons met onderhoudvoering begin het met die twee dogters gesels nie - ons het van verskeie persone verneem dat hulle nog besig was om die tragedie te verwerk. Vierdens wou ons inligting wat ons van die persone bekom het, toets aan die wat ons van bloedverwante en ander familie sou bekom (span 6).

- Ons het by die Polisie begin en na hulle 'verhaal' geluister asook gekyk na die video wat hulle van die moordtoneel gemaak het .... Na hierdie gesprek is die verdere strategic bespreek: Wic besoek gaan word, hoe onderhoude gevoer sal word, ens. Ons het begin by persoonlike vriende wat ook in dieselfde kerk as die oorledenes was - die doel was om eers die gesin te leer ken en te luister na moontlike ideosinkratiese kenmerke: beide as gesin en persoonlik (span 5).

Die navorsers het dus in hul onderhoudvoering probeer om inligting aangaande die moord in die eerste plek van persone te verkry wat nie in hegte, intieme verhoudings met die gesinne gewikkel was nie. Daar is geoordeel dat hulle relatief objektiewe data sou kon verskaf. Die inligting het die navorsers in staat gestel om 'n beeld van die gesin en sy rolspelers op te bou wat dan 'getoets' is aan gegewens wat verkry is van bloedverwante en ander persone wat intieme verhoudings met die oorledenes gehad het. Hierbenewens het die strategie die navorsers ook die geleentheid gebied om in daardie gevalle waar die moord hulle ontstel het, dit te verwerk voordat onderhoude gevoer is met gesinslede of ander persone wat intieme verhoudings met die oorledenes gehad het. Die strategie kon weens praktiese omstandighede egter nie in alle gevalle toegepas word nie.

4.3.2.5 Die navorsingskonteks. Tydens die versameling van die data het onderhoudvoering en waarneming in uiteenlopende kontekste geskied. Onderhoudvoering het in dorpe, stede en swart woongebiede; in psigiatriese hospitale, in nasorghostelle en spreekkamers; in 'n eskortagentskap, in 'n hotel, in die gevangenis, in 'n bloemistewinkel, in 'n apteek, in 'n kraal, op die strand, of by die moordtoneel geskied. Hierbenewens moes onderhoude soms laat en ten tye van politieke onrus gevoer word. Dit spreek vanself dat hierdie faktore die data wat ingesamel is, beïnvloed het. Die volgende is voorbeelde van situasies wat deur die navorsers as steurend uitgelig is:

- Die atmosfeer in die hele omgewing was gespanne; baie ANC-slagspreuke op gcboue, tekens van 'n uitgebrande motor ... Die jong konstabel meld aan twee lede dat hulle veiligheid nie verseker kan word nie en sé dan ook: "If they shoot, they shoot." Hy noem verder dat die jong mense motors afneem van mense wat in dic omgewing reis (span 10). 
- Sien moeder by bloemistewinkel. Sy werk alleen wat probleme veroorsaak hel, naamlik onderbrekings as gevolg van telefoonoproepe en kliënte (span 2).

- Die verskillende plekke waar ons data ingesamel het, het die navorsingsresultate natuurlik beïnvloed maar ongelukkig soms negatief. Hoewel die lokaliteite nie noodwendig altyd tot sydighede gelei het nie het dit beslis ons aandag en konsentrasie beïnvloed. Die ontsteltenis van die moordenaar se suster oor die feit dat die voog, die oorlede vrou se broer, laat blyk het dat sy nie altyd kontak met die twee dogters mag hê nie, het albei van ons minstens vir 'n paar minute laat vergeet dat ons in die eerste plek na inligting oor aanleidende omstandighede vir die moorde gesoek het (span 6).

Aansluitend by genoemde kontekseffekte is etlike gevalle van ongemotiveerdheid van die subjek as 'n steuringsfaktor beleef. Verskeie navorsers het gevoel dat sommige van hul subjekte die onderhoude as bedreigend ervaar het en indien hul nie onbetroubare inligting verskaf het nie, is belangrike inligting weerhou. Spanne 10 en 11 het veral dergelike probleme ondervind.

4.3.2.6 Strategieë om steuringsfaktore te minimaliseer. Daar is op verskeie wyses gepoog om navorser-, subjek- en kontekseffekte hok te slaan. Afgesien van opsigtelike slaggate (vgl. Olivier et al., 1991) is verskeie spesifieke strategieë soos die versekering van anonimiteit en die opbou van rapport geïmplementeer om die geldigheid van die data te maksimaliseer.

43.2.7 Afgesien van onderhoudvoerings is, van persoonlike dokumente en deelnemende waarneming gebruik gemaak om gegewens te versamel (vgl. Olivier $e t$ al., 1991).

- 4.3.2.8 Die verkreë data is met behulp van bandmasjiene en veldnotas vasgelê (vgl. Olivier et al., 1991).

43.2.9 Voorlopige data-analise. In kwalitatiewe navorsing kan die insameling van die data nie van die interpretasie daarvan geskei word nie. Hoewel 'n fase van intensiewe data-analise gewoonlik aan die einde van dergelike navorsing onderskei kan word, vind minstens 'n voorlopige vertolking van verkreë data voortdurend plaas. Voorlopige ontleding van die data het dan ook in die onderhawige ondersoek geskied, soos duidelik uit die volgende uittreksels geillustreer word:

- Patrone van gedrag en afwykings is gesoek, byvoorbeeld daar was sprake van die man wat scksueel promiskucus was - "Hy trek my uit met sy oê", het een van die vriendinne gesê. Elke aand het die 
lede van die ondersoekspan feite wat ingewin is geverifieer, hipoteses gestel en beplanning vir die volgende dag gedoen. Die hipoteses wat gestel is, is bevestig of verwerp (metodologieverslag deur $\operatorname{span} 1$ ).

- Tydens die ondersoek is patrone van gedrag en gedragsafwykings gesoek ... Elke aand tydens die verloop van die ondersoek of vroeg die volgende oggend het die spanlede feite wat ingewin is bespreek. Feite wat geverifieer moes word is uitgetig en daar is beplan by wie hierdie feite geverifieer kan word. Diskrepansies tussen getuienis van verskillende respondente is uitgelig en aandag is gegee tydens onderhoude met ander respondente om dit op te klaar. Beplanning is gedoen vir die dag en elke spanlid het onafhanklik van die ander spanlede sekere hipoteses vir die oorsake van die gesinsmoord geformuleer. Op die laaste dag van die navorsingsperiode is die hipotese wat elke spanlid opgestel het deur die span as geheel bespreek en na aanleiding van die bespreking en bewyse wat die hipoteses moes staaf, aanvaar of verwerp deur die meerderheidstem van die spanlede (metodologieverslag deur span 3 ).

- Na afhandeling van onderhoude het ons elkeen daaroor besin. Opsommings is saans gemaak waartydens na die bande geluister is. Hierna het ons in die motor normaalweg die volgende oggend onderweg vir ons volgende afspraak patrone wat deur ons elkeen opgemerk is of vermoedens wat by ons opgekom het bespreek. Hoewel ons ongelukkig weens 'n druk werksprogram wat cen van ons gehad het nie veldnotas opgestel het nie het die meer informele wyse waarvolgens ons die verkreë dala hanteer het in ons geval redelik goed gewerk. Ons het dan ook gevind dat dit beide van ons oor die tragedie en oor die gesin en sy akteurs laat teoretiseer het. Dit het ook meegebring dat ons tydens verdere onderhoude uitgevra het oor sake wat vir ons onduidelik was of on idees, spesmase en 'ontwikkelende' temas (metodologieverslag deur span 6).

43.2.10 Persoonlike en emosionele implikasies van die veldwerk. 'n Uitstaande kenmerk van kwalitatiewe navorsing is die intieme kontak tussen die navorser en sy subjekte. Hoewel dié noue kontak, soos reeds aangedui, die navorser in staat stel om die rykheid van mense se subjektiewe leefwêrelde te ontdek het dit uiteraard ook 'n uitwerking op die navorser self. Navorsers se ondenvindinge tydens veldwerk is tipies terselfdertyd aangenaam (bv. opwindend en verrykend) én onaangenaam (bv. ongerieflik en vermoeiend). Dit was ook die geval wat die onderhawige studie betref. Daar word met die volgende twee metodologiese notas volstaan wat van die belangrikste belewenisse van die navorsers weergee:

- Konflik in die grocp het ontstaan omdat ál die lede van die span nie 'n dag se werksaamhede kon afsluit, inligting bespreck en die nodige beplanning vir die volgende dag kon doen nie. Die redes was: die lede het in Pretoria in hul privaat woonhuise oornag en daar was 'n gebrek aan 'n "operasionele stasie", ander verpligtinge het lede se aandag vereis en van die lede was nie altyd bereid om na-ure te werk nie. Groepkohesie was swak en spanning in die span het opgebou - spanlede het vir mekaar kwaad geword. Om die navorsing voort te kon sit was dit nodig om eksterne hulp van buite dic span te kry om emosies te ventileer sodat die navorsingsproses kon voortgaan (metodologiesc verslag deur span 2). 
- Belewenis van spanwerk: As maatskaplike werker en as vrou, het ek dit positief beleef om 'n gesinsmoord saam met my manlike kollega (sosioloog) te ondersoek en wel om die volgende redes:

(a) Die besoek aan die byna leë huis wat half opgeruim was na die aaklige moord, het my aardig laat voel. Die teenwoordigheid van my kollega het my egter in so 'n mate gerus gestel dat ek onmiddellik na leidrade kon soek, wat ek ook gevind het (verskeie lee bottelijies pille).

(b) As redelike jong vrou is ek van mening dat ek gevoelsmatig makliker by die maatjies (van X en $Y$ ) kon aansluiting vind en werklik besef het hoe traumaties hulle hierdie gesinsmoord ervaar en hoe hulle na hul maats verlang. Gevolglik kon waardevolle inligting ingesamel word.

(c) Ons kon interessante menings wissel oor die huwelikskonflik van die moordenaar en sy oorlede vrou - ek uit die oogpunt van 'n vrou - hy uit die oogpunt van 'n man.

Tydens gesprekke tussen my kollega en respondente (en andersom) kon die ander party tyn waarnemings maak in terme van die respondente se nie-verbale kommunikasie en kon daarby aansluiting gevind word - met die gevolg dat 'n goeie verhouding met respondente opgebou is en hulle gevoel het iemand stel ook in hulle belang en nie net soos in die geval van verslaggewers wat net in inligting belanggestel het nie. Inderdaad was die onderhoude dus ook terapeuties van aard en het respondente selfs eie vrese met ons gedecl. - My kollega het my teenwoordigheid weer waardeer, veral wanneer hy ons aan respondente voorgestel het. Respondente was in die tydperk veral skrikkering vir vreemdelinge weens die publisiteit wat dic Van Rooyen-saak genict het.

- Persoonlike gevoelens tydens die ondersoek: As maatskaplike werker is ek al aan baie situasies blootgestel en leer 'n mens om eie gevoelens te bcheer. Tog ervaar 'n mens bepaalde cmosies en tydens hierdie ondersoek was ek bewus van die volgende:

(a) Die hartseer gevoel toe ek die huis sien waar mense cenmaal gelukkig was - waar duidelike tekens was dat die kinders winkel-winkel met hul ouers gespeel het, daar duidelike tekens was dat die huis eiehandig gebou is, dat daar selfs ' $n$ swembad en half-voltooide tennisbaan was vir gesinsplesier en in 'n oomblik was die menselewens uitgewis en het die materiēle verlatc agtergebly.

(b) Die diere - veral die honde - wat so bly was om icmand weer te sien. Hoc verduidelik 'n mens aan hulle dat hul oubaas en ounooi nooit weer sou lerug kom nie? Nog erger, die eens goed versorgde diere het ook reeds hul verlies fisies ervaar - hulle was vuil, vol vlooie en het die vlooie nie net vir hulle nie, maar ook vir ons 'opgeëet'. - Dat 'n man wat duidelik baie lief was vit sy gesin, doclbewus sagtepuntkoec̈ls gaan koop het - nie net om sy gesin uit te wis nie - maar dit nog op 'n baie kort afstand gedoen het (metodologiese verslag deur span 6 ).

Alvorens die bespreking van hierdie fase afgesluit kan word is dit nodig dat die aandag op twee sake gevestig word. Eerstens die behoefte aan 'n gerigter benadering wat tot etlike belangrike besluite gelei het. Die besluite is tydens die vergaderings van 1 Desember 1989 en 23 Maart 1990 geneem. Daar is naamlik onder meer besluit dat nader beweeg moet word na reeds bestaande konstrukte en dat dit in verband gebring 
moet word met die reeds verkreë data. Meer helderheid sou op dié wyse verkry kon word en sou besluit kon word of genoegsame inligting ingesamel is en of verdere gevalle benodig word. Uitsluitsel hieroor is, soos verderaan sal blyk, eers etlike maande later verkry. Die ander aangeleentheid wat van belang is, is die besluit dat met die oog op die evaluasie van die gehalte van die navorsingsresultate, die onderskeie spanne metodologiese verslae moes opstel. Die spanleiers moes naamlik aan die hand van riglyne wat deur die skrywer opgestel is herkonstrueer hoe hul spanne die gevalle ondersoek het.

\subsubsection{Die finale fase}

Hierdie fase het betrekking op die beëindiging van die studie. In die reël vind kwalitatiewe navorsers dit moeilik om hul studies af te sluit. "There is always one more person to interview, one more loose end to tie up, or one more area to pursue" (Taylor \& Bogdan, 1984:67). Behalwe wanneer omstandighede buite beheer van die navorser hom/haar noop om halt te roep (fondse wat uitgeput is, veranderde omstandighede van die subjekte, ens.), bereik die kwalitatiewe navorser 'n stadium wanneer min nuwe resultate verkry word. Dit is hierdie stadium wat Glaser en Strauss (1967) in gedagte het wanneer hulle sê dat 'n ondersoek se data op 'n tydstip 'versadig' raak. Die kwalitatiewe navorser is normaalweg op die stadium reeds gemoeid met intensiewe analise en sal die studie dan ook min of meer op hierdie stadium beëindig.

Wat die onderhawige ondersoek betref, is tydens die vergadering van die gesinsmoordprojekkomitee van 25-27 Oktober 1990 besluit om geen verdere gevalle van gesinsmoord te ondersoek nie, daar 'n goeie begrip van die gesinsmoordverskynsel uit die elf gevalle verkry is en die Departement die verslag reeds afgewag het.

Hierdie fase is veral gekenmerk deur 'n intensiewe ontleding van die data. Hoewel, soos reeds aangedui, data ook tydens die data-insamelingsfase ontleed is, is dit in hierdie fase meer doelgerig geklassifiseer en gekategoriseer. Daar is naamlik besluit dat (a) die verkreë data wat ingewin is deeglik deurgewerk moet word ten einde temas te identifiseer, (b) 'n uitvoerige studie van bestaande relevante konseptuele raamwerke onderneem moes word, en (c) die gegewens dan met behulp van (a) en (b) geïnterpreteer moes word. Om dit te kon bewerk, is twee werkkomitees tydens die vergadering van 23 Maart 1990 saamgestel, te wete die tema-komitee en die teorieë-komitee.

Die tema-komitee met prof. Dave Beyers as voorsitter se werkwyse kan soos volg saamgevat word: die lede het sonder om mekaar te beïnvloed die gevallestudies bestudeer 
en het temas geïdendifiseer waarna 'n grid opgestel is vir die verdere analise van die data. Die teorieë-komitee onder leiding van prof. Jan de Jongh van Arkel het 'n betreklik uitvoerige studie van relevante konsepte en teorieë van buitelandse sowel as plaaslike literatuur onderneem. Tweede-orde of abstrakte konstrukte is geïdentifiseer en benut in die finale interpretasie van die gegewens.

Tydens die vergadering van die gesinsmoordprojekkomitee of eerste Indaba by Goudrivier-Wildsoord is die afgebakende temas as vertrekpunt geneem en het die lede faktore wat met die verskynsel van gesinsmoord verband hou in die elf gevallestudies nagegaan. Die inligting wat met die gevallestudies bekom is, is hierna verder deur dr. Louise Olivier geïnterpreteer. Die interpretasie is gedoen met behulp van verslae oor gesinsmoordfaktore wat deur die spanleiers vir die projekleier opgestel is (temas/faktore is aan die hand van voorbeelde uit die gevalle geverifieer) asook aan die hand van relevante konstrukte uit die literatuurstudieverslag. Die verslag waarin die navorsingsresultate vervat is, is tydens ' $n$ tweede indaba by Goudrivier-Wildsoord gedurende 20 22 Februarie 1991 deur die gevallestudiekomitee bespreek waarna enkele wysigings aangebring, en dit gefinaliseer is. Die finale verslag is hierna deur dr. Louise Olivier en mev. Connie Haasbroek geredigeer en deur die outeurs goedgekeur.

Hoewel met voorafgaande uiteensetting van die belangrikste besluite en stappe van die ondersoek nie op volledigheid aanspraak gemaak word nie, word vertrou dat dit 'n aanduiding van die doeltreffendheid daarvan bied. Anders gestel, daar word gehoop dat die besluitnemingstappe genoegsaam geëkspliseer is sodat die leser die wetenskaplike geloofwaardigheid daarvan kan beoordeel. Aangesien kwalitatiewe navorsers vanweë die gebrek aan 'harde', streng, kontroleerbare en onbuigsame reéls gekonfronteer word met lastige vrae ten opsigte van die gebruiklike standaarde wat vir wetenskaplike navorsing gestel word, word vervolgens aangedui hoe die onderhawige studie dit ontmoet.

\section{DIE KWAI ITEIT VAN DIE DATA}

Alvorens aangetoon word hoe in die RGN-studie aan die eise van wetenskaplike geldigheid voldoen is, moet onthou word dat 'n kontekstuele navorsingstrategie oorwegend in die studie geïmplementeer is en dat om dié rede die klem val op interne geldigheid (die voortbring van akkurate bevindings en resultate wat in ooreenstemming is met die leefwèreld van die subjek). 
Die twee belangrikste aangeleenthede wat met interne geldigheid saamhang, is betroubaarheid en geldigheid.

Eersgenoemde het veral te make met konstantheid in die insameling, ontleding en interpretasie van die gegewens. Laasgenoemde verwys na die feit dat 'n besondere metode akkurate en werklikheidsgetroue resultate oor die verskynsel wat bestudeer is opgelewer het (Schurink, 1989:99)

Daar bestaan ' $n$ noue verband tussen die betroubaarheid en die herhaalbaarheid van 'n ondersoek. Die rede hiervoor word gevind in die argument dat indien 'n navorser in sy/haar ondersoek betroubare metodes gebruik, die ondersoek deur ander navorsers herhaal sal kan word en dat die gegewens wat hulle sal verkry nie beduidend van dié van die oorspronklike navorser sal verskil nie.

Kwalitatiewe navorsing is, soos meermale aangetoon is, hoogs veranderlik. Besluite en stappe word geneem onderwyl die navorsing uitgevoer word en nie voor die aanvang daarvan nie. Hoewel van hierdie besluite geboekstaaf kan word, is dit egter nie moontlik om alle stappe wat in 'n besondere ondersoek gevolg is, sodanig weer te gee dat dit 'n bloudruk sal verskaf aan ander navorsers wat dit wil herhaal nie.

Dit beteken egter nie dat die resultate van sodanige kwalitatiewe studie nie in verdere navorsing getoets sal kan word nie. Trouens, analitiese induksic (die onderhawige studie reflekteer ook elemente van dié ontledingsmetode) se klem op die soeke na gevalle wat bevindings weerspreek, moedig die verifikasie van resultate aan sonder dat die oorspronklike ondersoek herhaal hoef te word (Schurink, 1989:100)

Kwalitatiewe navorsing behoort in die lig hiervan beoordeel te word ooreenkomstig die mate wat dit verdere navorsing aanmoedig. Of soos Katz (1983:145) dit treffend stel:

Qualitative research reports properly may be regarded as good to the extent that readers test them in application to new data in the very process of reading. Underlying the reader's experience in 'recognizing' as valid or rejecting as 'artificial' an analytic formulation in a qualitative text is an implicit application to phenomena within the reader's experience, to new data existing beyond the reach of the original research.

Uit die voorgaande opmerkings blyk dat herhaalbaarheid in kwalitatiewe navorsing problematies is maar dat daar tog sprake van toetsing van bevindings deur sowel ander navorsers as lesers is. Dergelike oorwegings moet dan ook in gedagte gehou word in die evaluering van die onderhawige studie. 
Anders as kwantitatiewe navorsers wat geneig is om in verhouding tot betroubaarheid min aandag aan geldigheid te gee, le kwalitatiewe navorsers baie klem daarop. Daar is uiteraard ' $n$ hele aantal bronne van sydighede wat die geldigheid van navorsingsresultate in die wiele kan ry (vgl. Douglas (1976) en Mouton en Marais (1985)). Daar is reeds aangedui dat sommige van hierdie bronne ook die geldigheid van die RGNnavorsingsbevindinge bedreig het. Gevolglik word nie weer hierby stilgestaan nie. Die belangrikste strategiee wat tydens die studie aangewend is om die remmende faktore te bekamp is ook reeds aangestip. .'n Belangrike tegniek waarna nog nie verwys is nie en wat ook in die onderhawige studie geïmplementeer is, is dat in 'n poging om die nadelige uitwerking van steuringsfaktore teë te werk, gebruik gemaak is van trangulasie (Denzin, 1978) of intermetodiese kruisvalidasie (Mouton \& Marais, 1985). Hierdie tegniek "... dui op die gebruik van meerdere metodes wat deur hulle komplementariteit, die nadele van mekaar korrigeer" (Mouton \& Marais, 1985:91). In die onderhawige studie is van vier data-insamelingsmetodes gebruik gemaak, te wete: 'n literatuurstudie, deelnemende waarneming, indiepte-onderhoude en gedokumenteerde data. Daar kan geredelik aanvaar word dat die beperkinge wat die aanwending van 'n enkele metode meebring langs dié weg geminimaliseer is.

'n Strategie wat tipies in kwalitatiewe navorsing aangewend word om waarnemingseffekte te bekamp staan bekend as lidvalidasie (Gould et al., 1974) of lede se toetse van geldigheid (Douglas, 1976). Bloor (1983:157) beskryf hierdie strategie soos volg:

The member judges whether or not the sociologists' (or for that matter any social scientists') account seems familiar in that it refers to, and originates in, elcments similar to those in the member's stock of common sense knowledge.

Dit was ongelukkig nie in die ondersoek moontlik om die navorsingsresultate aan subjekte met wie goeie rapport opgebou is voor te lê nie.

Soos reeds aangedui, is daar verskeie faktore wat die gehalte van die resultate van enige navorsingsprojek bedreig. Hoewel dit naïef en voorbarig sou wees om te beweer dat al die faktore in die huidige studie geneutraliseer is, is die navorsers daarvan oortuig dat minstens die vernaamste steuringsfaktore wel genoegsaam geneutraliseer is en dat die ingesamelde data wel 'n hoë mate van geldigheid het.

\section{SAMEVATTENDE SLOTBESKOUING}

Die doel van hierdie artikel was tweeledig. Eerstens is die belangrikste besluitnemingstappe tydens die praktiese uitvoering van die RGN-ondersoek chronologies weerge- 
gee. Tweedens is geskets hoe in die studie te werk gegaan is om steuringsfaktore sover moontlik te neutraliseer ten einde gebruiklike wetenskaplike standaarde te handhaaf en terselfdertyd kwaliteitdata te bekom.

Kwalitatiewe navorsing is ' $\mathrm{n}$ verwikkelde en komplekse proses waartydens verskeie besluite en stappe normaalweg terselfdertyd geneem word. Hoewel dit uiteraard nie moontlik was om hierdie meerfasettige onderneming in hierdie bydrae in detail weer te gee nie, is dit nogtans in terme van die gebruike in die kwalitatiewe navorsingstyl genoegsaam beskryf sodat die leser die geloofwaardigheid daarvan kan evalueer. Sodanige evaluering kan uiteraard in die finale instansie slegs geskied indien die data wat in die verslag aangebied word ook aandagtig bestudeer word. Om dié rede is dit raadsaam dat lesers Olivier $e$ t al. (1991) sal bestudeer.

Ten slotte is dit belangrik dat in gedagte gehou sal word dat die onderhawige studie nie 'n volledige beskrywing bied van die verskynsel van gesinsmoord soos dit op 'n gegewe tydstip in Suid-Afrika manifesteer nie. Nogtans kan die ondersoek op 'n betreklik uitvoerige beskrywing van 'n aantal outentieke gevalle van gesinsmoorde aanspraak maak. Teen dié agtergrond kan hierdie navorsingsprojek dus getipeer word as 'n verkennend-beskrywende onderneming.

\section{BIBI JOGRAFIE}

ACKROYD, S. \& HUGHES, J.A. 1981. Data Collection in Context. New York: Longman. ATHENS, L.A. 1984. Scientific Criteria for Evaluating Qualitativc Studies. (In Denzin, N.K., ed. Studies in Symbolic Interaction, Vol. 5. Greenwich : JA1 Press. p. 259-268.)

BABBIE, E. 1989. The Practice of Social Research. Sth ed. Belmont, CA : Wadsworth.

BECKER, H.S. 1970. Sociological Work: Method and Substance. New York : Free Press.

BLOOR, M.J. 1983. Notes on Member Validation. (In Emerson, R.M., ed. Contemporary Field Research. A Collection of Readings. Boston : Little, Brown \& Co. p. 156-172.)

BOGDAN, R. 1972. Participant Observation. Syracuse : Syracusc University Division of Special Education and Rehabilitation.

BOGDAN, R. \& BIKLEN, S.K. 1982. Qualitative Research for Education: An Introduction to Theory and Methods. Boston : Allyn \& Bacon.

BOGDAN, R. \& TAYLOR, SJ. 1975. Introduction to Qualitative Research Methods: A Phenomenological Approach to the Social Sciences. London : Wiley.

BOGDAN, R. \& TAYLOR, S.J. 1990. Looking at the Bright Side: A Positive Approach to Oualitative Policy and Evaluation Research. Qualitative Sociology, 13(2):183-192.

BURGESS, R.G., ed. 1982. Field Research: A Sourcebook and Field Manual. London : Allen \& Unwin.

BURGESS, R.G. 1984. In the Field: An Introduction to Field Research. London : Allen \& Unwin.

BURGESS, R.G., ed. 1985. Strategies of Educational Research: Qualitative Methods. Philadelphia : Falmer. 
CHENITZ, W.C. \& SWANSON, J.M. 1986. From Practice to Grounded Theory; Oualitative Research in Nursing. Sydney: Addison-Wesley

DE JONGH VAN ARKEL, J.T. 1988. Gesinsmoorde: 'n toenemende verskynsel. UNISA Bulletin, 13(4):11.

DENZIN, N.K. 1978. The Research Act in Sociology: A Theoretical Introduction to Sociological Methods. 2nd. ed. Johannesburg : McGraw-Hill.

DOUGLAS, J.D. 1976. Investigative Social Research: Individual and Team Field Research. Beverley Hills, CA : Sage.

DU TOIT, S.I. 1990. Family Violence: Familicide. (In McKendrick, B. \& Hoffman, W., ed. People and Violence in South Africa. Cape Town : Oxford p. 288-300.)

EMERSON, R.M., ed. 1983. Contemporary Field Research: A Collection of Readings. Boston : Little \& Brown.

ENGELBRECHT, E. 1991. Slagoffers van bomaanvalle in Johannesburg: 'n kriminologiese ondersoek. Pretoria. (Ongepubliseerde D.Lit et Phil-proefskrif - UNISA.)

FIELD, P.A \& MORSE, J M. 1985. Nursing Research: The Application of Qualitative Approaches London : Croom Helm.

GLASER, B.G. \& STRAUSS, A. 1967. The Discovey of Grounded Theory: Strategies for Qualitative Research. Chicago : Aldine.

GOODWIN, L.D. \& GOODWIN, W.L. 1984. Are Validity and Reliability Relevant in Qualitative Evaluation Research? Evaluation and the Health Professions, 7(4):413-426.

GOULD, L. et al. 1974. Connections: Notes from the Heroin World. New Haven : Yale University.

GRASER, R.R. 1991. Family Murder in South Africa: Exploratory Notes. Acta Criminologica, 4(2):5054

GRASER, R.R. 1992. Victim and Victim Precipitation in Family Murders. (In Schurink, W.J.et al., eds Victimization. Nature and Trends. Pretoria : Human Sciences Research Council, p. 357-385.)

GUBRIUM, J. 1988. Analyzing Field Reality. Newbury Park, CA : Sage. (Qualitative Research Methods, Volume 8.)

HUGO, P., ed. 1990. Truth Be in the Ficld: Social Science Research in Southern Africa. Pretoria : University of South Africa. (Siudia composita 6.)

JORGENSEN, D.L. 1989. Participant Observation. A Methodology for Human Studics. Newsbury Park, CA : Sage. (Applied social research methods series, Volume 15.)

KATZ, J. 1983. A Theory of Oualitative Methodology: the Social System of Analytic Fieldwork. (In Emerson, R.M., ed. Contemporary Field Research; A Collection of Readings. Boston : Little \& Brown. p. 127-148.)

KIRK, Y. \& MILLER, M.L. 1986. Reliability and Validity in Qualiative Research. Beverly Hills : Sage. (Qualitative research melhods, Volume 1.)

LEININGER, M.M., ed. 1985. Oualitative Research Methods in Nursing. Orlando : Grune \& Stratton.

LOFLAND, J. \& LOFLAND, L.H. 1984. Analyzing Social Settings. 2nd cd. Belmont, California : Wardsworth

LOTTER, J.M. \& SCHURINK, W.J. 1986. Gevangenisbendes: 'n Ondersock met spesiale verwysing na nommerbendes onder kleurlinggevangenes. 2dc uitg. Pretoria : Raad vir Geesteswetenskaplike Navorsing (Verslag S-115.)

MARSHALL, C. \& ROSSMAN, G.B. 1989. Designing Qualitative Research. Newbury Park, California : Sage.

MINNAAR, A., OFFRIN(;A, D. \& PAYZE, C. 1992. To Live in Fear: Witchburning and Medicine Murder in Vcnda. Pretoria : Human Sciences Research Council (Report ASS/BBS-20.)

MOUTON, J. \& MARAIS, H.C. reds. 1985. Metodologic van dic geesteswetenskappe: Basiese begrippe. Pretoria : Raad vir Geesteswetenskaplike Navorsing. (RGN-studies in Navorsingsmetodes: 1.) 
MOUTON, J. 1988. Lesing 1: Die filosofie van kwalitatiewe navorsing. (In Ferreira, M. et al. Inleiding tot kwalitatiewe metodes. Pretoria : Raad vir Geesteswetenskaplike Navorsing. p. 1-13.) Lesings gelewer by die derde RGN-winterskool in navorsingsmetodologie.

NOTULE 1988. Vestigingskomiteevergadering. Pretoria.

OLIVIER, L. 1988. Family Murder as a Socio-Psychological Phenomenon in the Republic of South Africa. South African of Sociology, 19(3):117-119.

OLIVIER, L. et al. 1991. The Phenomenon of Family Murder in South Africa: An Exploratory Study. Pretoria : Human Sciences Research Council.

PARSE, R.R., COYNE, A.B. \& SMITH, M.J. 1985. Nursing Research: Qualitative Methods. Bovic, $\mathrm{MD}$ : Brady Communications.

PATTON, M.O. 1980. Qualitative Evaluation Methods. Beverley Hills : Sage.

PATTON, M.Q. 1990. Qualitative Evaluation and Research Methods. 2nd ed. Newbury Park, California : Sage.

PFAFFENBERGER, B. 1988. Microcomputer Applications in Qualitative Research. Newbury Park, CA : Sage. (Qualitative Research Methods, Volume 14.)

PLATT, J. 1981. Evidence and Proof in Documentary Research: 2. Some Shared Problems of Documentary Research. Sociological Review, 29(1):53-66.

PRETORIUS, R. 1982. Die bejaarde as slagoffer van misdaad. Pretoria. (Ongepublisecrde M.A.verhandeling - UP.)

PRETORIUS, R. 1987. Research on Family Violence in the Republic of South Africa. (In Steyn, A.F., Strijdom, H.G., Viljoen, S. \& Bosman, F.J., eds. Marriage and Family Life in Soulh Africa: Research Priorities. Pretoria: Human Sciences Rescarch Council. p. 417-445.)

PRETORIUS, R. 1990. Family Murder in the Republic of South Africa - a Case of Misguided Family Rights and Responsibilities? (In Viano, E.C., ed. The Victimology Handbook. Research Findings, Treatment and Public Policy. New York : Garland Publishing, Inc. p. 95-105.)

PUNCH, M. 1986. The Politics and Ethnics of Fieldwork. Beverly Hills : Sage. (Qualitative Research Methods, Volume 3.)

ROOS, J.L. \& BODEMER, R.W. 1989. Psigiatriese aspekte van gesinsmoord. Suid-Afrikaanse Mediese Tydskrif, 75:121-123.

SCHULZE, S. 1988. Homoseksuele identiteitsvorming in empiries-pedagogiese perspektief. Pretoria. (Ongepubliseerde D.Ed-proefskrif - UNISA.)

SCHURINK, W.J. 1979. Seksuele misdaad. (In Lōtter, J.M., Strijdom, H.G. \& Schurink, W.J. Eersterust: 'n sosiologiese studie van 'n kleurlinggemeenskap. Pretoria : Raad vir Geesteswetenskaplike Navorsing p. 3-22 tot 3-22-91.)

SCHURINK, W.J. 1981. Gay-vroue: 'n sosiologiese verkenning van die leefwyse van 'n aantal lesbièrs aan die hand van outobiografiese sketse. Pretoria : Raad vir Geesteswetenskaplike Navorsing (Verslag S-74.)

SCHURINK, W.J. 1989. Die realiteit van homoseksualisme: 'n Sosiologies-kwalitatiewe ontleding. Potchefstroom. (Ongepubliseerde D.Phil.-procfskrif - PUCHO.)

SCHURINK, W.J. \& NDABANDABA, L.B.G. 1991. Sex-for-money in Durban and Adjacent Residential Areas: An Exploratory Study of Some Features of Prostitution. Acta Criminologica, 4(2):34-49.

SCHURINK, W.J. \& WINTERBACH, D.J. 1979. "Seks-te-koop in diensorganisasies" - 'n sosiologiese verkenning van prostitusie in masseersalonne en eskorl-agentskappe. Pretoria : Raad vir Geesteswetenskaplike Navorsing. (Navorsingsbevinding S-N-174.)

SCHWARTZ, H. \& JACOBS, J. 1979. Qualitative Sociology: A Method to the Madness. New York : Free Press.

SHAFFIR, W.B. \& STEBBINS, A. eds. 1991. Experiencing Ficldwork. An Inside View of Qualitative Research. Newbury Park, CA : Sage. 
SMITH, R.B. \& MANNING, P.K., eds. 1982. A Handbook of Social Science Methods. Volume 2 Qualitative methods. Cambridge : Ballinger.

SNYMAN, S.H. 1989. Afrikaner-gesinsmoord: 'n ekologie van idees. Prctoria. (Ongcpubliseerde MA verhandeling - UNISA.)

STRAUS, A.L. 1987. Onalitative Analysis for Social Scientists. Cambridge : Cambridge University Press STRAUSS, A. \& CORBIN, J. 1990. Basics of Qualitative Rescarch. Grounded Theory, Procedures and Techniques. Newbury Park, CA : Sage.

TAYLOR, SJ. \& BOGDAN, R. 1984. Introduction to Qualitative Research Methods. 2nd. ed. New York: Wiley.

VAN MAANEN, J. 1979. Reclaiming Qualitative Methods for Organizational Research: A Preface. Administrative Science Quarterly, 24:520-526.

VAN MAANEN, J., ed. 1983. Qualitative Methodology. Beverley Hills : Sage.

VILJOEN, E. 1988. Moord binne families: 'n ekosistemiesc beskouing. Pretoria. (Ongepubliseerde M.A.-verhandeling - UNISA.)

WALKER, R., ed. 1985. Applied Qualitative Rescarch. Vermont : Gower.

WEIS, J.G. 1989. Family Violence Research. (In Ohlin, L. \& Tonry, M., eds. Family Violence. Chicago : The Universily of Chicago Press. p. 117-162.) Crime and Justice. A Review of Research. Vol. 11.

WESTER, F. 1987. Strategicën voor kwalitatief onderzotk. Muiderberg : Dick Coutinho. 
